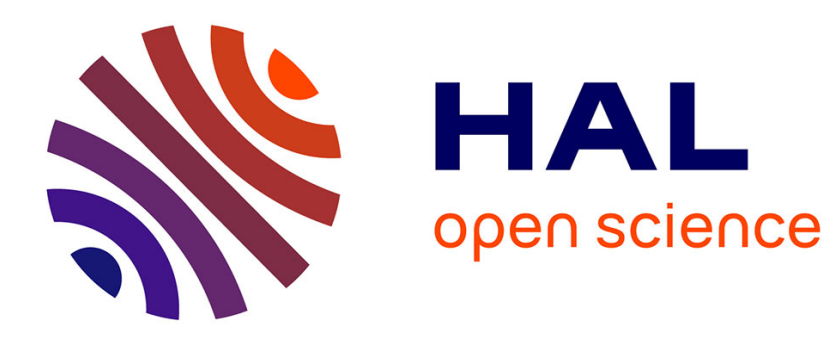

\title{
Seizing the Opportunity: Towards a Historiography of Information Systems
}

Nathalie Mitev, François-Xavier de Vaujany

\section{To cite this version:}

Nathalie Mitev, François-Xavier de Vaujany. Seizing the Opportunity: Towards a Historiography of Information Systems. Journal of Information Technology, 2012, pp.1-15. halshs-00671690

\section{HAL Id: halshs-00671690 \\ https://shs.hal.science/halshs-00671690}

Submitted on 8 Mar 2012

HAL is a multi-disciplinary open access archive for the deposit and dissemination of scientific research documents, whether they are published or not. The documents may come from teaching and research institutions in France or abroad, or from public or private research centers.
L'archive ouverte pluridisciplinaire HAL, est destinée au dépôt et à la diffusion de documents scientifiques de niveau recherche, publiés ou non, émanant des établissements d'enseignement et de recherche français ou étrangers, des laboratoires publics ou privés. 
Seizing the Opportunity:

\title{
Towards a Historiography of Information Systems
}

\author{
Nathalie MITEV \\ Department of Management \\ Information Systems and Innovation Group (ISIG) \\ London School of Economics and Political Science \\ Houghton Street \\ London WC2A 2AE \\ United Kingdom \\ n.n.mitev@1se.ac.uk
}

\author{
François-Xavier DE VAUJANY \\ Equipe de recherche Management \& Organisation \\ DRM (UMR CNRS 7088) \\ Université Paris-Dauphine \\ Place du Maréchal de Lattre de Tassigny \\ 75016 Paris \\ France \\ devaujany@dauphine.fr
}

\section{SHORT TITLE:}

Historiography of Information Systems 


\section{ABSTRACT:}

Historical perspectives are only timidly entering the world of IS research compared to historical research in management or organization studies. If major IS outlets have already published history-oriented papers, the number of historical papers - although increasing - remains low. We carried out a thematic analysis of all papers on History and IS published between 1972 and 2009 indexed on ABI and papers indexed in Google Scholar ${ }^{\mathrm{TM}}$ for the same period. We used a typology developed by theorists Usdiken and Kieser (2004) who classify historical organisation research into supplementarist, integrationist and reorientationist approaches. We outline their links with the epistemological stances well known in IS research, positivism, interpretivism and critical research; we then focus on their differences and historiographical characteristics. We found that most IS History papers are supplementarist descriptive case studies with limited uses of History. This paper then suggests that IS research could benefit from adopting integrationist and reorientationist historical perspectives and we offer some examples to illustrate how that would contribute to enriching, extending and challenging existing theories.

KEYWORDS: IS history; historiography; historical methods; historical organization theory. 


\section{$\underline{\text { INTRODUCTION }}$}

Since the late 90 s, a stream of research in IS has been promoting historical perspectives on organizational information systems (Mason et al, 1995, 1997a, 1997b; Bannister, 2002; Porra, et al, 2005; Land, 2010). The adoption of historical sensitivity is likely to be helpful in a field that is often driven by the 'awesome potential' of advanced ICTs. We often lose sight of issues as we are blinded by the glare of technology (Bannister, 2002; Land, 2010). If we acquire a historical dimension we may avoid regurgitating ideas with little awareness of their historical context, and being victims of IT fads and fashions (Westrup, 2005) which often damage the potential competitive advantage of firms. A lack of historical consciousness means that concepts and themes are often repackaged several years on, with little thought given to their historical context and origin (Bannister, 2002).

In contrast, an historical approach to organizations and their technological capabilities is an opportunity to develop reflexivity and criticism. It is a way to combat the universalistic and 'presentist' tendencies of general so-called management theory, or 'Heathrow Organisation Theory' after Gibson Burrell (1997). The latter allows business researchers to escape without any real sensitivity to the issues raised by the humanities and social sciences, to view technology as neutral, technical progress as natural, and to 
view History ${ }^{1}$ as hagiography (success stories, e.g. Peters and Waterman, success of IBM) rather than historiography.

From a managerial perspective, historical approaches can also help explore differently organisational assets through historical narratives about and by organisations (Brunninge, 2009) - for instance new elements for brand image, original corporate identities, memory, communication (Delahaye et al, 2009), culture (Barney, 1986) or forgotten products or processes (e.g. quality management, see Karsten et al, 2009). Corporate History has a relative malleability (Gioia et $a l, 2002)$ and is a resource managers use for differentiation (Foster et al, 2009).

Searching both for theoretical and methodological benefits, management and organization studies have experienced a move towards History (see Goodman and Kruger, 1988; Kieser, 1989, 1994). According to Clark and Rowlinson (2004), the historic 'turn' represents a transformation of organization studies in three senses, and this could apply equally well to IS research:

- Turn against the view that organization studies should constitute a branch of the science of society;

- Turn towards history, conceptualizing the past as process and context rather than as a variable;

- Turn to historiographical debates and historical theories of interpretation which recognize the inherent ambiguity of the term History itself. 
Indeed, the use of historical perspectives has been criticized, in the fields of organization theory (Clarke and Rowlinson, 2004; Usdiken and Kieser, 2004; Kieser, 1994), management (Goodman and Kruger, 1988; O'Brien et al, 2004) and information systems (Bannister, 2002; Land, 2010) for its lack of achievement.

Clarke and Rowlinson (2004) provide a critical analysis of historical efforts in organisation studies. They argue that there have been minor rather than major applications of historical methods; for instance the discourse of contingency and strategic choice still seeks to identify universal characteristics, even if it is to allow for some variation between historical contexts. Research tries to include historical variability but still tends towards deterministic and universalist explanations. Some approaches like new institutionalism and organisational ecology have become more historical - with longitudinal studies of organisational fields and populations or use of large-scale historical databases. But their time frame is usually only a chronological time-line and presumes a linear account of history. Overall, organisation studies have only carried out limited historical research (Ibid). The same question can be raised about IS research. According to Land (2010), one can wonder if History is not (still) a "missed opportunity". We argue here that there are ways of avoiding "simple data dredging" (Goodman and Kruger, 1988) and we will make some suggestions to revisit and seize this historical opportunity. 
This paper starts by examining IS historical research through a conceptual framework commonly used in management and organisation studies (Usdiken and Kieser, 2004) in order to evaluate the use of History in IS research systematically. We explain this framework by relating it to the epistemological viewpoints of positivism, interpretivism and critical theory which are well-accepted in IS research and we briefly outline corresponding historiographical methods. We then use this historical conceptual framework to analyse a large data set of IS History papers and provide suggestions for further historical IS research.

\section{HISTORIOGRAPHICAL METHODS IN ORGANIZATION THEORY: A}

\section{CONCEPTUAL FRAMEWORK}

Usdiken and Kieser $(2004)^{2}$ have developed a typology which is summarised in Table 1. They classify different degrees of incorporation of historical approaches in organizational and management research and suggest that they fall into three categories:

- supplementarist, where historical 'context' is simply added and is only a complement to common positivist approaches still focusing on variables, although with a longer time span than usual. It "adheres to the view of organization theory as social scientistic ${ }^{3}$ and merely adds History as another contextual variable, 
alongside other variables such as national cultures" (Booth and Rowlinson, 2006:

$8)$;

- integrationist, or a full consideration of History with new or stronger links between organization theory and history. The aim is "to enrich organization theory by developing links with the humanities, including history, literary theory and philosophy, without completely abandoning a social scientistic orientation" (Ibid: 8);

- and reorientationist or post-positivist, which examines and repositions dominant discourses including our own (such as progress or efficiency), and produces a criticism and renewal of organization theory itself, on the basis of history. This "involves a thoroughgoing critique of existing theories of organization for their ahistorical orientation" (Ibid: 8).

Usdiken and Kieser (2004) claim that supplementarist research seems to be more frequent in organization theory than integrationist and reorientationist organizational research.

\section{$<$ INSERT TABLE 1 ABOUT HERE $>$}

Examples of historical supplementarist approaches in management and organization studies are how neo-institutional economics use historical analyses of corporate formations. Approaches like new institutionalism have become more 'historical': they study a small number of variables over longer historical periods, but usually are not rich contextual case studies of organizations on a long-term timescale. Their emphasis is on 
persistence and homogeneity, and they exhibit a fear of lapsing into narrative interpretations of historical events that stress their complexity, uniqueness and contingency.

Examples of integrationist work can be found in the business History perspective applied to the world of organizations. Business historians have progressed to realise the potential of their work to inform contemporary managerial decision-making. More interpretivist and inductive analyses of History in organisational studies (Kieser, 1989, 1994) have abandoned 'general models' that are conceptualised independently of the phenomena to be explained. They are longitudinal case studies which try to account for subtle temporal and institutional dimensions, use processual (as opposed to factor) approaches and focus on contextual differences, organizational change and culture.

Reorientationist approaches are present in the History of management, and of management ideas and thought. They move beyond the following false dichotomy: whether History is merely a literary or narrative form, designed for political and moral edification ('Heathrow Organisation Theory'); or a science, designed for explanation of the past and prediction of the future (scientist analytical schemas) in which the logic of efficiency has been superimposed onto the narratives of historians. The so-called 'efficiency principle' militates against both historical and ethical considerations. It presumes that History is efficient, and it subordinates History to conceptual modelling. But reorientationist research is rare in organization studies (Usdiken and Kieser, 2004). 
These three perspectives make sense in the field of History itself, which has always drawn on multiple epistemological stances. For clarification purposes, we relate the supplementarist-integrationist-reorientationist typology to the three epistemological positions of positivism, interpretivism and critical research, well known in IS research (Hirschheim, 1985; Orlikowski and Baroudi, 1991; Walsham, 1993, 1995; Klein and Myers, 1991).

Etymologically, History is an inquiry ( $\sigma \tau o p i ́ \alpha$ [Historíai] means 'inquiry' in Greek). Historiography can refer either to the History of History, or to the investigation of historical methods (Furay and Salevouris, 2000). Our focus here is more on the latter, in relationship with epistemological stances.

Positivistic researchers have defined History as driven by the search for truth, that is to say, 'facts' (Carr, 1961; Seignobos, 1901). Carr wanted to "show how it really was" (1961:3 quoted by Bannister, 2002). In classical historical research (Simiand, 1903) this often focuses on:

- Chronologies which underscore the genealogy of present structures and habits and avoid the details specific to any particular period;

- Centring History on the biography of individuals who embody a certain historical trend (like the common success and heroic stories in management);

- Political ideas, i.e. giving priority to political History which underlines political ideology and trends, whose importance is often exaggerated; 
- National interests (Le Goff, 2006) based on, or even legitimating, national frontiers. Continental or international world analyses are rarely carried out by classic historians.

A positivist historian will search for triangulation of traces and clues to get the 'real' picture of a context located in the past. Other researchers in historiography have challenged this view and proposed viewing History in a more interpretivist and critical way - see for instance Aron's (1938) invitation to work out a critical philosophy of History by drawing on Dilthey, Rickert, Simmel, and Max Weber. According to an interpretivist stance, Collingwood (1993) suggests defining History as "the study of thought"; History is the "re-enactment in the historian's mind of the thought whose History he/she is studying". Marrou (1954) invited historians to adopt a critical stance by concentrating on the fuzzy boundary between the study of the present and that of the past; she proposed that "from a logical point of view, there is nothing specific in understanding related to the past. It involves the same process as the understanding of others in the present, in particular (as most of the time and in the best situation, the document taken into account is a "text") the comprehension of articulated language" (p.83).

A critical historiographical perspective (Le Goff, 2006: 73) invites historians to "build a new scientific chronology which dates phenomena according to the duration of their effectiveness in History instead of the starting-point of their production". In other words, the emphasis is more on tracing the long-term effects and discourses associated with certain phenomena instead of the phenomena themselves. This leads to a stronger focus on institutions and social structures rather than isolated actions in organizations, and is a 
good way to answer Braudel's (1958) well-known call for a "longue durée" (or longterm) perspective in history. There are few major social theories which are ahistorical or neglectful of this longue durée perspective. For instance institutionalism, evolutionism and structuration theory are all based on long-term historiographical logic and often, long-term observations.

To explain this further, let's look at one of the most fundamental questions debated in history: whether there is a 'typical' historical theorization of social transformations within societies and organizations. An example in IS research could be the typical conceptualization of IT providing a competitive advantage and transforming organizations which is (has been?) very dominant. This key question could be reversed. This would mean investigating its historiography i.e. the long-term duration of this conceptualization in its historical institutional and social context; for instance, the emergence of the notion of IT and competitive advantage in the context of deregulation and liberalisation in specific situations (e.g. US airlines which pioneered the use of IT for competitive advantage with SABRE in the 1980s), the relationship of IT to the shaping of free markets, and the social and economic effects on industry de/restructuring. It deuniversalizes these conceptualisations, provides a critical analysis of their effectiveness and leads to more sophisticated theorizations. Similarly, Sauer (2008: 65, 75) has argued that "capitalism has motivated the exploitation of IT (...) for its potential rather than its actual value"; and more generally that historical 'backcasting' reveals "series of mutual adjustments" rather than outputs of a linear model. 
Although there is an apparent link between Usdiken and Kieser's three categories and the respective epistemologies of positivism, interpretivism, and critical historical research above, there is an important difference. According to Orlikowski and Baroudi (1991: 56):

"Positivist studies are premised on the existence of a priori fixed relationships within phenomena which are typically investigated with structured instrumentation. Such studies serve primarily to test theory, in an attempt to increase predictive understanding of phenomena.", whilst interpretive studies "assume that people create and associate their own subjective and intersubjective meanings as they interact with the world around them." (Ibid: 5). In contrast, "critical studies aim to critique the status quo, through the exposure of what are believed to be deep-seated, structural contradictions within social systems, and thereby to transform these alienating and restrictive social conditions." (Ibid: 5-6).

Whereas these three epistemologies are based on three distinctive views of knowledge and the social world, supplementarist, integrationist and reorientationist approaches form a continuum. This continuum is about the way in which the reference discipline (organisation studies or information systems in our case) is challenged by the historical approach. At the lowest end of the spectrum, supplementarism only adds History without affecting the premises of theory; for instance seeking correlations between variables (presumed to be stable) of organizational change over time. Integrationism goes a little further in identifying historical processes of, for instance, organisational change over 
time, although it still aims to improve theories; at the highest end, conceptualizations of organizational change theories themselves are questioned through the reorientationist historical perspective.

In addition, we believe that interpretivism (as described by Walsham, 1993) can be integrationist or even re-orientationist; but that re-orientationism does not uniquely correspond to an interpretive perspective. Some reorientationist work can adopt an interpretivist, or even a positivist approach to critically de-construct organization theory. On the other hand, we see a more direct correspondence between supplementarism (e.g. in its understanding of time and actors) and positivism, Integrationism can be positivist or interpretivist but not critical. Rather than just adopting different epistemological stances, historical approaches operate on a continuum:

- consolidating existing theories (supplementarist, positivist, never critical),

- extending theories (integrationist, positivist or interpretivist), or

- challenging theories (re-orientationist, positivist or interpretivist, and always critical).

An element of critical approaches, as already quoted above, is the exposure of deepseated contradictions (Orlikowski and Baroudi, 1991). To achieve this, an important tenet of criticality is the centrality of discourse where the constitutive powers of language are emphasised and 'natural' or 'universal' objects are viewed as discursively and historically produced. This idea grew out of the 'linguistic turn' in French post- 
structuralist philosophy; it opposes the objectivists on the one hand, with their science aimed at predicting / controlling nature and people, and humanists on the other for privileging the individual's reported experience and a naïve version of human freedom (see Mitev and Howcroft, 2011). For instance, the Foucauldian version views discourses as systems of genealogical thought which are contingent upon, as well as informing, material practices (see Willcocks 2004). Thus, tracing the historical emergence of 'strategy' discourses at a particular time can lead to identifying deep seated contradictions, including the sustaining and enhancement of the prerogatives of management, the generation of a sense of personal security for managers, the expression of a gendered masculinity, and the facilitation and legitimisation of the exercise of power (Alvesson and Deetz, 1996). A reorientationist perspective challenges theories (here strategy, see also Knights and Morgan, 1991, 1995) and is an often neglected element of critical approaches in management. Critical IS research in particular was initially guided by the emancipatory Frankfurt school and many have argued (e.g. Howcroft and Trauth, 2004) that the relative dominance of the Habermassian approach is unnecessarily limiting and have suggested that other approaches may be of benefit; we believe historical perspectives can contribute.

There have been tense debates about historiography as a method. Beyond the issue of the existence of specific historical methods (Veyne, 1971), History is a material which is handled, analysed and narrated by historians. Historians process materials left by past actions through access to recorded events. Those can be written or oral, based on monuments (archaeology is close to history), pictures, objects or documents. To select 
their primary material and develop an historical account, historians traditionally rely on the sets of criteria and associated questions outlined below (Langlois and Seignobos, 1897). Although positivist in their orientation, these criteria are still a deep part of historical rigour, whatever the epistemological position. They apply mainly to textual artefacts.

- External criteria: they deal with the physical features of materials under study (e.g. paper, ink or seals). To authenticate a document, skills in palaeography or epigraphy are often required. Historians of computing (e.g. Campbell Kelly, 2010) include artefacts such as algorithms.

- Internal criteria: these are related to the internal coherence/consistency of a text, i.e. examining whether different parts of a text are coherent with one another.

- Source criteria: where does this material come from? This is often a way to evaluate the authenticity and accuracy of a testimony. In a corporate environment, a leaflet will not be valued in the same way as personal notes in a retired chairperson's diary. The temporal distance between events described and the period of their writing/formalizing in the document will also be taken into account.

- Range/target criteria, related to the receiver of a text. In what ways the artefact may have been received by people of that time? What could have been the expectations of the builder/sender of the artefact? How did s/he frame it to anticipate receivers' response? 
Additionally, Garraghan (1946) has suggested the following six types of questions corresponding to some of these criteria. These questions show great potential for the study of IS and computer programmes in organizations.

- When was the document/artefact written (date)? - External

- Where was it produced (localization)? - External

- By whom (authorship)? - Source

- From what pre-existing materials (analysis)? - Source

- In what original form (integrity)? - Internal

- With what evidential value (credibility)? - Internal

Beyond this critical examination of materials, historical methods focus on either the elaboration of a set of events (with the aim of constructing them 'objectively') or the understanding of perceptions/representations (or interpretations) of actors involved in a specific spatio-temporal setting. For a positivist historian, facts will be isolated and then gathered according to their similarity or topicality. Each fact is linked to a cause or a set of causes which will be uncovered through a systematic study of materials. For a more interpretivist historian, imagination will play a stronger role. S/he will have to put himself/herself in the shoes of remote (in time and space) stakeholders of the society, organization, tribe, etc. under study.

Eventually, whatever the epistemological stance (positivist, interpretivist or critical), comes the time of writing/narrating history. This stage of research has been thoroughly 
investigated recently with the 'linguistic turn'. According to Munslow (2001: 1), "the recognition that History is a narrative about the past written in the here and now, rather than some distanced mirror of it, has been a significant issue within the profession for several years". We believe that current debates in IS research about interpretivist and critical research could be renewed through an exploration of historiography, which can help address two key interdependent pitfalls ${ }^{4}$ : anachronism and acontextuality (Booth and Rowlinson, 2006).

Organizational scholars should give time serious consideration (see Orlikowski and Yates, 2002). Indeed, in many so-called historical studies, it is often assumed that "any society, from the prehistoric to the present, faces the same organizational problems as our own". Anachronism, presentism and universalism dominate. Universalism often "emphasizes continuity over change" (Booth and Rowlinson, 2006: 6). Many organizational studies are not anchored enough in time, space and context. They present "fictionalized organizations in a non-dated, extended present." The historic turn problematizes universalism and presentism:

"It raises the question of the extent to which organizations, and organizational research need to be historicized, that is, located in a specific historical context. For example, was the multinational enterprise born in ancient Greece? Or is it a form of organization that is specific to a globalized, capitalist economy? In which case, were the forms of foreign direct investment during the first age of globalization comparable to those of the late 20th century? And in terms of the 
present, how generalizable across time and space are the findings of an ethnographer from a fictionalized and supposedly typical organization?" (Booth and Rowlinson, 2006: 6).

There have been similar calls by Kieser $(1989,1994)$ for more interpretivist and inductive analyses of History in organisational studies and for abandoning 'general models' that are conceptualised independently of the phenomena to be explained.

Can the same difficulties be noticed in IS research? Has IS research been mainly supplementarist, integrationist or re-orientationist? How historical has been positivist, interpretivist and critical IS research? How can we revisit the opportunity offered by historiography (see Land, 2010)? These will be the issues which will be addressed next. We first examine existing historical IS research critically, using Usdiken and Kieser's (2004) classification to rank different degrees of incorporation of historical approaches into IS research. We then illustrate what the potential could be for historical analyses of IS.

FROM HISTORICAL PERSPECTIVES IN ORGANIZATION THEORY TO HISTORICAL PERSPECTIVES IN IS RESEARCH 
In order to examine how historical approaches have been applied to IS research, we first present a thematic analysis of all papers on History and IS found through a systematic search of the ABI bibliographic database. We classify them using Usdiken and Kieser's (2004) typology already presented in the introduction above. Using a further search of Google Scholar ${ }^{\mathrm{TM}}$ and pre-existing literature reviews, we then propose a qualitative analysis of a few papers typical of each of Usdiken and Kieser's categories in order to discuss the main trends identified.

We provide an overview of IS papers with an historical perspective. In order to do this we concentrated on refereed journal articles since they are the type of publication that are regarded as being of highest quality, as compared to international conference papers or books ${ }^{5}$. Our concern is with papers deemed to be of a standard sufficiently high for international journal publication and thereby legitimised as worthy of interest to an international community. In addition, we focused specifically on journals that were located within the IS discipline and only considered papers which were located unequivocally within this literature. The journals chosen had information systems as their primary focus as opposed to management science, computer science, or information science. We selected journals whose principal readership is intended for those involved in the IS field.

The aim of this literature review is to provide an illustration of the quantity and nature of the types of papers that have been published in IS journals. We do not claim that the survey is exhaustive; nor do we assume that a more comprehensive survey (e.g. including 
conference proceedings or using other databases) would deliver significantly different results. The analysis involved the identification of all research papers in ABI that might broadly be defined as a historical perspective on information systems. Using a further search on Google Scholar ${ }^{\mathrm{TM}}$ (http://scholar.google.com/) $)^{6}$, we double checked our primary analysis in order to confirm general tendencies and identify complementary references, used in our discussion. Therefore, in our survey of relevant literature our intention is to focus on material that is published in outlets specifically targeted as IS. Our research goal is to learn how a historical perspective has been incorporated into the IS literature.

We constructed a data set by retrieving all academic papers with the words "information systems" and "history" (in citation and abstract) from ABI. Our search focused on full text academic papers. This resulted in 384 papers from 1972 to 2009. Among the 384 papers, we found a lot of irrelevant papers, i.e. papers using the word History from a technical perspective (e.g. "historical customer data") or only incidentally. We identified only 64 papers which were historical in their content. We then used the three dimensions mentioned earlier (supplementarist, integrationist, reorientationist) to code each paper (see Appendices 1 and 2 for raw data and additional analysis). The results are presented in a succinct form in Tables 2 and 3 . An extract of the full list of papers identified on ABI along with their analytical coding can be found in Appendix 3.

<INSERT TABLES 2 AND 3 ABOUT HERE> 
The main findings are:

- The very small number of historical papers (only 64 from 1972 to 2009, see also Appendix 3);

- A limited use of History for challenging theories (only 1.6\% of reorientationist papers);

- The sharp increase of supplementarist papers consolidating existing theories (in particular in the 2000s, see also Figure 1);

- The fact that there is a moderate number of IS journals (see Table 1). Many interesting papers we found were published in journals in information science, history, computer science or economics.

Beyond this, historical IS papers follow a pattern: almost entirely absent reorientationist papers, a steady increase of integrationist publications and a dramatic increase of supplementarist articles (see Figure 1). History is therefore entering IS research through supplementarism (i.e. longer time-span of data collection and a focus on processes rather than variables or factors). From the mid nineties, it seems nonetheless that an increasing number of (integrationist) papers borrowed theories, concepts or methods from history. But this does not result in specific IS historical perspectives. Perhaps this is due to the fact that IS phenomena are relatively recent so historical 'data' are only slowly 
accumulating and IS scholars need historical distance to be able to distinguish long-term historical trends.

\section{$<$ INSERT FIGURE 1 ABOUT HERE $>$}

Our additional analysis based on Google Scholar ${ }^{\mathrm{TM}}$ produces the same results as our ABI analysis (see Appendix 4). From the 70s to the early 2000s, we identified 190 papers. The bulk was published in the 90s, with an increase in the late 90s. In addition, most articles were not published in IS journals and could be classified as supplementarist or integrationist (although we did not carry out such a systematic analysis as the one we did with $\mathrm{ABI})$. 


\section{DISCUSSION}

From Long-term Research to Historiography

Analysing these historical papers shows that: most are a description of events broadly covering a couple of decades of IS, within a single organization (see Land, 2000; Maier et al, 2002; D'Arcy et al, 2008; Chen and Hirschheim, 2004); some focused on using a few historical concepts or techniques applied to a broader time scale (Robey and Newman, 1996; Mason et al, 1997a, 1997b; Yates, 1997, 1999); researchers often relied on second hand data; their theorisation was not strongly linked to History; they developed concepts which could have been developed on the basis of non-historical data; and they did not include long-term analyses or broader institutional contexts. This is also confirmed by a more general analysis of historical papers, by means of Google Scholar ${ }^{\mathrm{TM}}$ (see Appendix 4), complemented by Bannister $(2002)^{7}$ and previous literature reviews by de Vaujany (2006) and Mitev and Howcroft (2005).

Clearly, historical research on organizational information systems has been relatively rare (Bannister, 2002). The Porra, Hirschheim and Parks' (2005) History of the Texaco corporate information technology functions, Yates' work $(1999,2005)$ on the structuring of early computer use in the life insurance industry, Winter and Taylor's (2001) analysis of the role of IT in proto-industrial and post-industrial organizations, or the Harvard MIS 
History project (Mc Kenney et al, 1995) are among the rare, often cited references of historical works by IS scholars. Outside IS research, some historians of computing have also been interested in organizational computer systems. For instance, Wells (2000) studied artefacts and outdated computers in Wall Street and Heide (2004) analyzed record management systems in France between 1935 and 1944.

If some of this research has adopted a descriptive stance shedding light on the evolution of various forms of IS, there are few writings in IS that have worked out a historiography of IS. Among the rare historiographical conceptualizations within the field, Mason et al (1997a, 1997b) and Yates $(1997,1999)$ are worth examining further.

Mason et al first suggest that there are three main roles, which can be endorsed by historical figures: the leader (identifying phases of crisis), the "maestro" (mastering key business or technological domains) and the "supertech" (who will develop relevant innovations to overcome the crisis). Second, they propose two key concepts; in their notion of cascade, these researchers insist on the importance of discontinuities in the flow of events, which is very close to the well-known notion of punctuated equilibrium and strategic alignment (see Majchrzak et al, 2000). Following a crisis, IS would gradually converge to a balanced configuration of technology and human assets. This conceptualization of historical change proposes a three-part method consisting in the identification of key roles and variables, the specification of units of analysis, and the gathering of evidence. 
Other IS historical studies have drawn on interpretive frameworks. For instance, Yates based her work on Giddens' structuration theory (Yates, 1997, 1999). Her method is less based on crisis identification and more on everyday continuous enactment of structure.

To better understand the supplementarist, integrationist and reorientationist approaches to IS History and their implications, we examined a sample of papers in more depth (see Table 4).

\section{$<$ INSERT TABLE 4 ABOUT HERE>}

Supplementarist research tends to have a descriptive understanding of historical research to consolidate existing IS theories. For instance, Simon et al (2009, see also Table 4) juxtaposed the History of a leading US multinational company and its offshore vendors with the literature on offshore outsourcing to refine attributes of best practices/maturity for a model for mature IT governance. By contrast, Mason et al (1997a, 1997b) can be classified as integrationist; they use historical evidence to build and extend the theory that IT has become "the most influential force leading to restructuring of business and political economy as a whole". Their aim is to "reveal how IT forces have changed businesses, organisations, and industries" and they draw on the Schumpeterian creative/destructive approach to economic cycles. Their research base is "exemplary" ITbased business histories to "demonstrate" the effects of investments in IT on companies, industries and societies, exemplified by the Harvard MIS History Project. It consists of 
accounts of success stories at Bank of America (McKenney et al, 1997), American Airlines, FedEx, Bank One, Wal-Mart, Frito-Lay and American Hospital Supply.

Studies for explaining IS in organisations can present both historical accounts and multivariate analysis, using a supplementarist approach, but can also expand into integrationist approaches to enrich IS theories. Accordingly, they recognise that present organisational forms and socio-technical arrangements have been shaped by past events (e.g. economic cycles) and their course of development has been influenced by the broader historical context. It implies turning to: processes of organisational and institutional change over time; development of organisational forms and variations across societal settings; path dependencies and continuities in organisational ideas and practices over time; historically specific material, social and cultural settings and their relations with organisations and technologies - these settings can include education, national institutions, economic and political history, the role of the State, religion, etc.

Supplementarist and integrationist stances dominate our ABI findings, and reorientationist research is rare. Reorientationist perspectives could challenge existing theories, generate new research questions as well as look at old questions in new ways (Usdiken and Kieser, 2004). By anchoring research findings more clearly to their social origins can push thinking about alternative explanations for phenomena, help identify more and less stable concepts, and expand research horizons. The reorientationist historical approach can help frame theory and research within their time-related boundaries, and provide perspective on the present through the past. Reorientationism helps confront current and popular organisational and managerial ideas with practices in the past likely to reveal continuities and similarities. Studying the fate of earlier 
approaches and their features enables critical assessments of ideas that are currently promulgated. Universalist ahistorical stances are challenged and debates around what is made of History and how it is done are favoured.

For instance, revisiting the well-known stock of pioneer IT success stories would help understand how these discourses constituted our world at certain times and in certain spaces, and what their deep seated contradictions were. It would expose universalist Chandlerian heroic accounts of how particular technical solutions were seen as yielding superior results, and the effects of 'ideal types' of IT innovation such as cascade and crisis. Examining these mechanisms in the past would help understand the History of our intellectual constructs and their own historicity and help challenge the construction of current theories. As avenues for further historiographical research in IS, some of the ways in which History can help to extend or reshape IS theoretical underpinnings are explored further below.

\section{$\underline{\text { Suggestions for Further Research }}$}

From the integrationist perspective, we believe a longue-durée historiographical outlook can help grasping the specificity of the institutional context of IS design, use or implementation in contemporary organizations. An example of a long-cycle approach is Martins' (2009) study of first-tier managers' roles from the industrial revolution to the $21^{\text {st }}$ century which concludes that "if key factors are not considered from an in-depth 
historical perspective (...) the people management role will remain a major organisational dilemma". Neo-institutional frameworks (DiMaggio and Powell, 1983; Scott, 2001), structuration theory (Giddens, 1984), evolutionary economics (Nelson and Winter, 1982) or social critical realism (Archer, 1995), to name but a few, can help modelling the dynamic of society, organizational fields or populations of organizations. Such theories can help understanding sociotechnical path-dependencies (Van Driel and Dolfsma, 2009). Notions such as increasing returns, lock-in or self-reinforcement are promising ways to extend organizational perspectives (Page, 2006). Models used in IS such as absorptive capability, critical success factors of IT project management or strategic alignment models of IS could be extended by the inclusion of these broader institutional factors and their history. Such is also the case of rising sociomaterial approaches (see Orlikowski, 2007). The integration of long-term perspectives could be a way to make sense of materiality and the evolution of its social meaning through time.

From a reorientationist perspective, historiography could also be a way to deconstruct IS frameworks and their relationship to managerial decision-making. Indeed, organizational History (and of information systems), could be conceptualized as a managerial asset; historians have shown that corporate History has a relative malleability (Gioia et al, 2002). It is a resource managers can use for differentiation (Foster et al, 2009). Firstly, because narratives about IT itself can become a differentiating myth, like the famous SABRE case-study (Hopper, 1990; Copeland, 1991). There has been debate (Adam, 1990; Monteiro and Mcdonald, 1996; Mitev, 2004) about whether SABRE really helped to gain a competitive advantage per se, when there were other major influences such as 
airline deregulation. But what it clear, is that this software has become a differentiating myth for American Airlines. Long-term History of financial, human and technical resources can help conceptualise further how the combination of resources over the History of an organization evolves (see Penrose, 1959) and is intertwined with IT (Porra et al, 2006).

Historiography can also be a way to narrate IS differently and challenge existing theories, through more reflexive approaches. Examples in management studies which could inspire IS researchers are: Cooke's (1999) historiography of the concept of change management; Zan's (1994; 2004) History of accounting histories; and the historical institutional analysis by Caswill and Wensley (2007) on how relevance and rigour have been constituted in management research in the UK. A critical example about the History of IS is Haigh's (2001) historical exploration of the role and vested interests of various professional bodies in 'inventing' information systems. Rayward (1996) uses Braudel's notions of 'longue', 'moyenne' and 'courte durée' to provide a new perspective on the History of information science; and the notions of synchrony and diachrony ${ }^{8}$ to suggest other approaches to its historical study, in particular its interdisciplinarity over time.

The work of historians such as Le Goff (2006) could be an inspiration to write our scientific articles, books, case narratives differently, maybe in a more innovative and a more critical way. Grey and Sinclair (2006) suggest critical forms of writing to address aesthetic, moral and political concerns and ask questions on what our ways of writing accomplish in political terms. Using historical fiction is another example of writing 
which opens up the possibility of new critical insights (Czarniawska, 1999); and so is the use of History for critically examining management education (Down, 2001; Zald, 2002). Finally, and more reflectively, Hatchuel and Glise (2003) propose a redefinition of management research based on a historical analysis which could also be carried out in IS research.

Beyond suggesting these broad avenues for further research, we now illustrate what these avenues could look like. We concentrate in particular on two re-orientationist examples since our main finding is that there is very little evidence of reorientationist IS research, so it may be more difficult to carry out. We expand two IS topics which we think lend themselves to a critical reorientationist analysis: outsourcing/centralisation with a positivist reorientationist approach; and action research/empowerment with an interpretivist reorientationist approach.

The History of the 'putting out' systems (Kieser, 1994) could be compared to current outsourcing and issues of de/centralisation. Putting out was a complex network of contracts of manufacture, usually analysed through labour process analysis (workers' control of product and process, division of labour, factory systems, technical superiority, matching of technology with skills, family lives) during the industrial revolution in Western societies, especially the UK. Historical material shows that putting out was a consequence - rather than the cause - of a division of work that was already in existence across rural communities in the North West of England in the textile industry. The centralisation of production was triggered by the need to fill the capacity of large-scale 
machinery, but putting out systems were far more effective than the centralized factory. Factory owners were forced to compromise as they were unable to find a technology for decentralised production. One could see parallels with the contracting out of workers through increasingly mobile ICTs, which takes place within countries and globally across borders, as opposed to just within regions. It may be possible to contrast and compare across cases, to highlight features particular to each historical context in order to gain some unexpected insights into current practices. While we are not suggesting that History repeats itself, informed historical analyses could serve to reflect on current thinking and critique existing theories of IT-enabled work design, for instance the consequences of offshoring on communities both in Southern and Northern parts of the world (see Howcroft and Richardson, 2010).

The historiography of influential ideas and thinkers on action research and change management could bring insights into the topic of participatory design and empowerment through ICTs. Cooke (1999) looked at the work of Kurt Lewin (1946), who is noted for the development of action research in organizational studies. Action research methods are concerned with changing the social system through engagement on the part of the researcher with the intention of making a contribution to social problems. However, action research was originally developed to deal with 'minority' problems, group dynamics and race relations, in a context of inter-ethnic conflict (US black apartheid). And participatory anthropology had been used by the British Empire and its liberal colonial administration's principle of 'indirect rule'. This principle was the stimulus for the development of action research, throwing an ambiguous light on the origins and aims 
of these methods, providing an interesting lens through which query current participatory or community based technologies.

Similarly, Cooke (1999) also examined how the change management discourse has rewritten its own History and how its very construction has been a political process ${ }^{9}$, which has excluded a certain understanding of radical change, and "shaped an understanding of change as technocratic and ideologically neutral”. Change management deals with the 'correct' understanding of the need for change and of who the subjects of change are. Cooke (1999) argues that Edgar Schein (1961) incorporated 'radical' ideas into the dominant management orthodoxy of the time and that his change management techniques draw on representations of an oriental 'other', in the context of a US military opposing liberation struggles in Asian countries. Participatory 'liberation' management does not question the right of those controlling the process. Social political and ideological circumstances in which it is applied are assumed to be uncontested and objectively given. Change management is therefore analysed as arising from drives to make 'subjects', whose voices are never represented, manageable. The current and growing use of ubiquitous managerial technologies to empower IT users and employees could be examined with these histories in mind.

\section{CONCLUDING REMARKS: AN HISTORICAL OPPORTUNITY}

Our literature survey and classification of IS historical journal papers over the last 38 years show that IS historical research has mainly been supplementarist (confirming 
existing theories) rather than integrationist (extending theories) or reorientationist (questioning theories), although the two latter have potential for a critical understanding of IS-related organisational changes. In the last section, we have made proposals to inspire integrationist and reorientationist historical IS researchers. Reviewing examples in related disciplines such as business history, management and organizational history and the social history of technology may provide further inspiration and broaden the scope of IS History research in the future.

There are still debates within the discipline of History, in particular about the focus on discourses and the use of historical narratives. Linear narratives tend to attribute a causal relation between events which is misleading. And historians have a problem with the indifference to the origin and context of historical texts. But the focus on metaphors, material/cultural practices and historically based analyses of discourses about technologies, can help reject scientific and historical notions of 'progress' (e.g. technological progress), avoid inferences of causality and universal truths, and bring some distance on present organisations and technologies by making them unfamiliar. As Rowlinson and Carter (2002: 400) state:

"History is about lies, not truth. It is a struggle for domination acted out in a play of wills $(\ldots)$ in order to demonstrate the historical specificity of $(\ldots)$ organisations that have generally been overlooked in the discourse of organisation studies, historical research is required (...) and that necessitates the provision of concrete histories of organisations, practices and institutions". 
We can add here concrete histories of their information systems and technologies in order to enrich, extend and question existing theories about their rationales, uses and effects. Whether IS researchers will be interested in carrying out this type of research in order to refute Ford's provocative statement "History is bunk" (Land, 2010) remains to be seen. 


\section{$\underline{\text { REFERENCES }}$}

Adam, R. (1990) A license to steal? The growth and development of airline information systems, Journal of Information Science, 16(2): 77-91

Alvesson, M. and Deetz, S. (1996) Critical theory and postmodernism approaches to organizational studies, in Handbook of Organization Studies, edited by S.R. Clegg, C. Hardy and W.R. Nord, Sage Publications, Thousand Oaks, pp. 191-217. [Reprinted in Grey, C. and Willmott, H. (2005) Critical Management Studies: A Reader, Oxford University Press (Oxford Management Readers), Oxford, pp. 60106].

Archer, M. (1995) Realist Social Theory: The Morphogenetic Approach, Cambridge: Cambridge University Press.

Aron, R. (1938) Introduction à la philosophie de l'histoire. Essai sur les limites de l'objectivité historique, Paris: Gallimard.

Bannister, F. (2002) The dimension of time: historiography in information systems research, Electronic Journal of Business Research Methods, 1(1): 1-10.

Barney, J.B. (1986) Organizational culture: Can it be a source of sustained competitive advantage? Academy of Management Review. 11(3): 656-665.

Booth, C. and Rowlinson, M. (2004) Management and organizational history: Prospects. Management \& Organizational History, 1(1): 5-30.

Braudel, F. (1958) La longue durée. Annales, 4(Oct-Nov): 725-753.

Burrell, G. (1997) Pandemonium: Towards a retro-organization theory. London: Sage. 
Brunninge, O. (2009) Using History in organizations: how managers make purposeful reference to History in strategy processes, Journal of Organizational Change Management, 22(1): 8-26.

Campbell-Kelly, M. (2010) Historical reflections: Victorian data processing, Communications of the ACM, 53(10): 19-21.

Campbell-Kelly, M. and Aspray, W. (1996) Computer: A History of the Information Machine, New York: Basic Books

Carr, E. (1961) What is history? London: Macmillan Press.

Caswill, C. and Wensley, R. (2007) Doors and boundaries: a recent History of the relationship between research and practice in UK organizational and management research, Business History, 49(3): 293-320.

Chen, W. and Hirschheim, R. (2004) A paradigmatic and methodological examination of Information systems research from 1991 to 2001. Information Systems Journal, 14(3): 197-207.

Clark, P. and Rowlinson, M. (2004) The treatment of History in organisation studies. Towards an 'historic turn'? Business History, 46(3): 331-352.

Collingwood, R. (1993) The idea of history: with lectures 1926-1928. Oxford: Oxford University Press.

Cooke, B. (1999) Writing the left out of management theory: The historiography of the management of change. Organization 6: 81-105.

Copeland, D.G. (1991) So you want to build the next Sabre system?'Business Quarterly, Winter: 56-60. 
Czarniawska, B. (1999) Writing management: Organization theory as a literary genre. Oxford: Oxford University Press.

D'Arcy, C., Holman, J., John Bass, A., Rosman, D.L. and Smith, M.B. (2008) A decade of data linkage in Western Australia: strategic design, applications and benefits of the WA data linkage system, Australian Health Review. 32(4): 766-778.

Furay, C. and Salevouris, M.J. (2000). The Methods and Skills of History: A Practical Guide, NY: Harlan Davidson, second edition.

de Vaujany, F.X. (2006) Conceptualizing IS archetypes through history: the case of the Roman Curia, in International Conference on Information Systems (ICIS), (Milwaukee, Wisconsin, Dec 2006).

Delahaye, A., Booth, C., Clark, P., Procter, S. and Rowlinson, M. (2009) The genre of corporate history, Journal of Organizational Change Management, 22(1): 27-48.

DiMaggio, PJ. \& Powell, W. (1983) The iron cage revisited: institutional isomorphism and collective rationality in organizational fields, American Sociological Review, 48: $147-60$.

Durepos, G. and Mills, A.J. (2010) Actor-network theory: ANTi-History and critical organizational historiography, Academy of Management Annual Meeting (Montreal, 6-10 August 2010).

Down, S. (2001) The use of History in business and management learning, and some implications for management learning. Management Learning, 32: 393-410.

Elbanna, A.R. (2002) Information Technology and Organisational Transformation: History, Rhetoric and Practice, Information Technology \& People, 15(2): 175179. 
Foster, W.M., Suddaby, R. and Wiebe, E.M. (2009) Organizational History and tradition: Can it be the source of a sustained competitive advantage? in 25th European Group on Organisation Studies (EGOS) Colloquium (Barcelona, Spain, July 2009), Sub-theme 43: Historical perspectives in organization studies.

Garraghan, JG. (1946) A Guide to Historical Method, New York: Fordham University Press.

Giddens (1984) The Constitution of Society. Outline of the Theory of Structuration. Cambridge: Polity.

Gioia, D. A., Corley, K. G., and Fabbri, T. (2002) Revising the past (while thinking in the future perfect tense), Journal of Organizational Change Management, 15(6), 622.

Goodman, R.S. and Kruger, E.V. (1988) Data Dredging or Legitimate Research Method? Historiography and Its Potential for Management Research, The Academy of Management Review, 13(2): 315-325.

Grey C. and Sinclair, A. (2006) Writing differently, Organization, 13(3): 443-453.

Haigh, T. (2001) Inventing information systems: the systems men and the computer, 1950-1968, Business History Review, 75(1): 15-61.

Hartt, C.M., Durepos, G. and Mills, A.J. (2009) Performing the Past: ANTi-History, Gendered Spaces and Feminist Practice. 26th European Group on Organisation Studies (EGOS) Colloquium (Lisbon, June 2010).

Hatchuel, H. and Glise, H. (2003) Rebuilding management: a historical perspective, in Collaborative research in organisations: foundations for learning, change and theoretical development. N.Adler et al., (ed.), Thousand Oaks, USA: Sage Publications. 
Heide, L. (2004) Monitoring People: Dynamics and Hazards of Record Management in France, 1935-1944. Technology and Culture, 45(1): 80-101.

Hirschheim, R.A. (1985) Information systems epistemology: an historical perspective, in Research Methods in Information Systems, E. Mumford, R. Hirschheim, G. Fitzgerald (eds.), North-Holland: Amsterdam, pp. 13-38.

Hopper, M.D. (1990) Rattling Sabre: news ways to compete on information, Harvard Business Review, 68(3): 118-125.

Howcroft, D. and Richardson, H. (eds) Work and Life in the Global Economy: A Gendered Analysis of Service Work, Basingstoke: Palgrave Macmillan, 284 pp.

Howcroft, D. and Trauth, E.M. (2005) Choosing critical IS research, in Handbook of Critical Information Systems Research, edited by D. Howcroft and E.M. Trauth, Edward Elgar, pp. 1-16.

Karsten, L., Keulen, S., Kroeze, R and Peters, R. (2009) Leadership style and entrepreneurial change: The Centurion operation at Philips Electronics, Journal of Organizational Change Management, 22(1): 73-91.

Kieser, A. (1989) Organizational, institutional and societal evolution: Medieval craft guilds and the genesis of formal organizations, Administrative Science Quarterly, 34: 540-64.

Kieser, A. (1994) Why organization theory needs historical analyses - and how this should be performed, Organization Science, 5(4): 608-620.

Klein, H. K. and M. D. Myers (1999). A set of principles for conducting and evaluating interpretive field studies in information systems, MIS Quarterly, 23(1): 67-88. 
Knights, D. and G. Morgan (1991). Corporate strategy, organizations and subjectivity: A critique, Organization Studies 12(9): 251-273.

Knights, D. and G. Morgan (1995). Strategy under the microscope, Journal of Management Studies 33(2): 191-214.

Knights, D. and F. Murray (1994). Managers Divided: Organisation politics and information technology management. Chichester, John Wiley.

Land, F. (2000) The first business computer: a case study in user-driven innovation, IEEE Annals of the History of Computing, 22(3): 16-26.

Land, F. (2010) The use of History in IS research: An opportunity missed? Journal of Information Technology. Oct 2010.

Langlois, C.V. and Seignobos, C. (1897) Introduction aux études historiques. Paris: Editions Kime (Collection Sens de l'Histoire), 1992.

Le Goff, J. (1996) Saint Louis, Paris: Gallimard. (Available in English: Le Goff, J. and Gollrad, G.E. Saint Louis, University of Notre Dame Press, 2009).

Le Goff, J. (2006) (eds), La nouvelle histoire, Paris: Complexe Editions.

Lewin, K. (1946) Action research and minority problems. Journal of Social Issues 2(4): $34-46$.

Maier, J.L., Greer, T. and Clark, J.F. (2002). The management information systems (MIS) job market late 1970s-late 1990s. The Journal of Computer Information Systems. 42(4): 44-50.

Martins, L-P. (2009) The nature of the changing role of first-tier managers: a long-cycle approach, Journal of Organizational Change Management, 22(1): 92-123. 
Mason, R., McKenney JL and Copeland, D. (1997a) An Historical Method for MIS Research: Steps and Assumptions, MIS Quarterly, 21(3): 307-320.

Mason R.O., McKenney, J.L. and Copeland, D.G. (1997b) Developing an Historical Tradition in MIS Research, MIS Quarterly, 21(3): 257-278.

Majchrzak, A., Rice R.A., Malhotra, A., King N, and Ba S. (2000) Technology Adaptation: The case of a computer-supported inter-organizational team, MIS Quarterly, 24(4): 569-600.

Marrou, H.I. (1951) L'Histoire et ses méthodes, Paris : Editions Bibliothèque de la Pléiade.

Marrou, H.I. (1954) De la connaissance historique, Paris : Editions du Seuil.

McKenney, J., Copeland D. and Mason R. (1995) Waves of Change: Business Evolution Through Information Technology, Boston: Harvard Business School Press.

McKenney, J.L., Mason, R.O. and Copeland, D.G. (1997) Bank of America: the crest and trough of technological leadership, MIS Quarterly, 21(3): 321-353.

Mitev, N.N. (2004) Trains, planes and computers: from high-speed trains to computerised reservation systems, Journal of Transport History, 25(2): 101-123.

Mitev, N.N. and Howcroft, D.A. (2005) The role of History in IS research. In Critical Management Studies (CMS) Conference (4-6 July 2005 : Cambridge, UK).

Mitev, N. and Howcroft, D. (2011) Poststructuralism, Science and Technology Studies and Actor Network Theory: what can they bring to IS research? In Oxford Handbook of Management Information Systems, edited by Bob Galliers and Wendy Currie, Oxford University Press.

Monteiro, L. and S. Macdonald, (1996) From efficiency to flexibility: the strategic use of 
information in the airline industry, Journal of Strategic Information Systems, 5: 169-188.

Munslow, A. (2001) What History is, History in Focus, Issue 2 (What is History?), University of London. http://www.history.ac.uk/ihr/Focus/Whatishistory/ munslow6.html.

Nelson, R. and Winter, S. (1982) An evolutionary theory of economic change, Harvard: Harvard University Press.

O’Brien, J., Remenyi, D. and Keaney, A. (2004) Historiography - A neglected research method in business and management studies, Electronic Journal of Business Research Methods, 2(2): 135-144.

Orlikowski, W. J. (2007). Sociomaterial practices: Exploring technology at work. Organization Studies, 28(9): 1435-1448.

Orlikowski, W. J. and J. J. Baroudi (1991). Studying information technology in organizations: Research approaches and assumptions, Information Systems Research 2(1): 1-28.

Orlikowski, W.J. and J. Yates (2002). It's about time: temporal structuring in organizations. Organization Science 13(6): 684-700.

Page, S (2006) Path Dependence. Quarterly Journal of Political Science, 88.

Penrose, E.T. (1959) The Theory of the Growth of the Firm, New York: Wiley.

Pollock, N. and Williams, R. (2008) Software and Organisations: The Biography of The Enterprise-wide System or How SAP Conquered The World. London: Routledge. 
Porra, J., Hirschheim R., and Parks M.S. (2005) The History of Texaco's corporate information technology function: a general systems theoretical interpretation, MIS Quarterly, 29(4).

Porra, J., Hirschheim, R. and Parks, M.S. (2006) Forty years of the corporate information technology function at Texaco Inc. - A history, Information and Organization, 16: 82-107.

Rayward, W.B. (1996) The History and historiography of information science: some reflections, Information Processing and Management, 32(1): 3-17.

Robey, D. and Newman, M. (1996) Sequential patterns in information systems development: an application of a social process model, ACM Transactions on Information Systems, 14(1): 30-63.

Rowlinson, M. and Carter, C. (2002) Foucault and History in organization studies. Organization, 9(4): 527-547.

Rowlinson, M., Clark, P., Delahaye, A., Booth, C. and Procter, S (2008)The Uses of History as Corporate Knowledge. in The Evolution of Business Knowledge, $\mathrm{H}$. Scarbrough (ed.), Oxford: Oxford University Press, pp. 339-356.

Sauer, C. (2008) The Technology of the Possible - IT, Innovation, Capitalism and Globalisation, in S. Dopson, M.J. Earl, and P. Snow (Eds.), Mapping the Management Journey: Practice, Theory and Context, Oxford: Oxford University Press, pp. 63-79.

Scott, W. R. (2001) Institutions and Organizations. Thousand Oaks, CA: Sage.

Seignobos, C. (1901) La méthode historique appliquée aux sciences sociales, Paris: F. Alcan. 
Schein, E.H. (1961) Coercive persuasion: a socio-psychological analysis of the "brainwashing" of American civilian prisoners by the Chinese Communists, New York : W. W. Norton.

Simiand, F. (1903) Notes critiques Sciences sociales, pp. 4-6. Also published in Simiand, F. (1987) Méthode historique et sciences sociales. Paris: Éditions des archives contemporaines, pp. 177-78.

Simon, J.C., Poston, R.S. and Kettinger, B. (2009) Creating Better Governance of Offshore Services Information Systems Management. Vol. 26, Iss. 2; p. 110

Üsdiken, B. and Kieser, A. (2004) Introduction: History in Organization Studies, Business History, 46: 321-330.

Van Driel, H. and Dolfsma, W. (2009) Path dependence, initial conditions and routines in organizations: the Toyota production system reexamined, Journal of Organizational Change Management, 22(1): 49-72.

Veyne, P. (1971) Comment on écrit l'histoire. Essai d'épistémologie. Paris: Seuil.

Walsham, G. (1993) Interpreting information systems in organizations. Chichester: Wiley.

Walsham, G. (1995) Interpretive case studies in IS research: nature and method. European Journal of Information Systems, 4(2): 74-81.

Wells, W. (2000) Certificates and computers: the remaking of Wall Street 1967-1971. Business History Review, 72: 193-235.

Willcocks, L.P. (2004) Foucault, Power / Knowledge and Information Systems, In Social Theory and Philosophy for Information Systems, edited by L. Willcocks and J. Mingers, John Wiley, Information Systems Series pp. 238-296. 
Winter, S and Taylor L. (2001) The Role of Information Technology in the Transformation of Work: A Comparison of Post-industrial, Industrial and ProtoIndustrial Organization. in Yates, J. and J. Van Maanen (Eds.) Information Technology and Organizational Transformation: History, Rhetoric and Practice, London: Sage, pp 7-34.

Westrup, C. (2005) Management Fashions and Information Systems. In Handbook of Critical Information Systems Research: Theory and Application, Howcroft D. and Trauth E.M. (eds.), London: Edward Elgar.

Yates, J. (1997) Using Giddens' structuration theory to inform business history, Business and Economic History, 26(1).

Yates, J. (1999) The structuring of early computer use in life insurance, Journal of Design History, 12(1): 5-24.

Yates, J. (2005) Structuring the Information Age: Life Insurance and Information Technology in the 20th Century, Johns Hopkins University Press.

Zald, M. (2002) Spinning disciplines: Critical management studies in the context of the transformation of management education. Organization, 9: 365-385.

Zan, L. (1994) Toward a History of Accounting Histories. European Accounting Review. 3(2): $255: 307$.

Zan, L. (2004) Accounting and management discourse in protoindustrial settings: The Venice Arsenal in the turn of the XVI Century, Accounting and Business Research, 32: 145 - 175. 
${ }^{1}$ To improve understanding we use the traditional distinction between 'history' (the past) and History (historical science).

${ }^{2}$ For broader discussions about historical approaches in management and organization studies, see a new journal set up in 2006: Management \& Organization History (http://moh.sagepub.com/). This unique journal corresponds to a community of organizational historians which departs from the business history community, through its focus on "the study of management, organizations and organizing". It is related to a regular track at the European Group in Organizations Studies (EGOS) conference about "historical perspectives in organizations studies" (see http://www.egos2012.net/2011/06/sub-theme-08-swg-historical-perspectives-inorganization-studies/).

${ }^{3}$ Scientism refers to a belief in the universal applicability of the systematic methods and approach of science, especially the view that empirical science constitutes the most authoritative worldview or most valuable part of human learning, to the exclusion of other viewpoints.

${ }^{4}$ Booth and Rowlinson use the metaphors of the "Flintstone method" and the "Simpsons method" to describe these two situations.

${ }^{5}$ Books are clearly a better example of historical research and there are a few in IS. However, the pressures on researchers to publish in journals have grown enormously and there are hardly any rewards in publishing research monographs, particularly in business schools. This is another debate. 
${ }^{6}$ Based on the same search terms as for ABI, see Appendix 3.

${ }^{7}$ Beyond the references mentioned in this paper, see also Bannister's website for an inventory of IS historical literature: http://is2.lse.ac.uk/leo/historio.htm.

${ }^{8}$ Synchronic analysis views phenomena only at one point in time, usually the present; a diachronic analysis regards a phenomenon in terms of developments through time.

${ }^{9}$ This is a good example of what we meant earlier by historiography as the History of History.

Table Erreur ! Document principal seulement.. A typology of historical perspectives in organization studies

(adapted from Usdiken and Kieser, 2004)

\begin{tabular}{|c|c|c|}
\hline $\begin{array}{c}\text { HISTORICAL } \\
\text { STANCES } \\
\text { IN ORGANIZATION } \\
\text { STUDIES }\end{array}$ & PRINCIPLE & EXAMPLES \\
\hline $\begin{array}{c}\text { Supplementarist } \\
\text { historical perspective } \\
\text { (i.e. peripheral use of } \\
\text { history) }\end{array}$ & $\begin{array}{l}\text { Longer time-span than } \\
\text { usual case studies. } \\
\text { Limited use of } \\
\text { historical concepts, } \\
\text { theories or methods. } \\
\text { Descriptive } \\
\text { approaches. } \\
\text { Consolidate existing } \\
\text { theories. } \\
\text { Positivist stance. }\end{array}$ & $\begin{array}{l}\text { Structural contingency and strategic } \\
\text { choice seek to identify salient universal } \\
\text { contingencies even if it is to allow for } \\
\text { variation between historical contexts. It } \\
\text { tries to explain variability but tends } \\
\text { towards determinism. } \\
\text { See most research under the umbrella of } \\
\text { the 'Heathrow theory' critique (Burrell, } \\
\text { 1997) }\end{array}$ \\
\hline
\end{tabular}




\begin{tabular}{|c|c|c|}
\hline $\begin{array}{l}\text { Integrationist } \\
\text { historical perspective } \\
\text { (i.e. use of History to } \\
\text { extend existing } \\
\text { theoretical } \\
\text { frameworks) }\end{array}$ & $\begin{array}{l}\text { Integration of } \\
\text { historical techniques } \\
\text { and theories into } \\
\text { organizational } \\
\text { research. Extension of } \\
\text { existing theories. } \\
\text { Extending theories. } \\
\text { Positivist or } \\
\text { interpretivist stance. }\end{array}$ & $\begin{array}{l}\text { Approaches like new institutionalism } \\
\text { and organisational ecology have } \\
\text { become more historical with } \\
\text { longitudinal studies of organisational } \\
\text { fields and populations, cross-sectional } \\
\text { studies or use of large-scale historical } \\
\text { databases. Their time frame is usually a } \\
\text { simple time-line with a basic } \\
\text { chronological account of history. } \\
\text { See Kieser's (1989) work about } \\
\text { monastic organizations which is a way } \\
\text { to extend classic research about } \\
\text { bureaucracy or proto-bureaucracy. }\end{array}$ \\
\hline $\begin{array}{l}\text { Reorientationist } \\
\text { historical perspective } \\
\text { (i.e. extensive use of } \\
\text { historical data and } \\
\text { historiography to } \\
\text { deconstruct existing } \\
\text { theoretical frameworks } \\
\text { and to propose new } \\
\text { ones) }\end{array}$ & $\begin{array}{l}\text { Reorientation of } \\
\text { organizational } \\
\text { research (i.e. new } \\
\text { organization theories) } \\
\text { on the basis of } \\
\text { historiography. } \\
\text { Challenging theories. } \\
\text { Critical stance. }\end{array}$ & $\begin{array}{l}\text { Reorientationist approaches are more } \\
\text { present in the History of management, } \\
\text { and of management ideas and thought. } \\
\text { They help identify and analyse the } \\
\text { following cliches: } \\
\text { - History neglected and/or used to } \\
\text { support a narrative about powerful new } \\
\text { claims ('Heathrow Organisation } \\
\text { Theory'); } \\
\text { - History as science, designed for } \\
\text { explanation of the past and prediction of } \\
\text { the future (scientism). } \\
\text { See Actor Network Theory based } \\
\text { critical organizational historiographical } \\
\text { analyses (Hartt et al, 2009; Durepos } e t \\
\text { al, 2010). }\end{array}$ \\
\hline
\end{tabular}

Table 2 Relative distribution of IS historical papers

\begin{tabular}{|l|c|c|c|c|}
\hline & $\begin{array}{c}\text { Number of } \\
\text { historical } \\
\text { papers per } \\
\text { category }\end{array}$ & $\begin{array}{c}\text { Percentage of } \\
\text { historical } \\
\text { papers per } \\
\text { category }\end{array}$ & $\begin{array}{c}\text { Number } \\
\text { of papers } \\
\text { in IS } \\
\text { journals }\end{array}$ & $\begin{array}{c}\text { Percentage in } \\
\text { IS journals }\end{array}$ \\
\hline Supplementarist & 34 & $53.1 \%$ & 19 & $59.38 \%$ \\
\hline Integrationist & 29 & $45.31 \%$ & 11 & $37.5 \%$ \\
\hline Reorientationist & 1 & $1.56 \%$ & 1 & $3 \%$ \\
\hline Total & 64 & $100 \%$ & 31 & $100 \%$ \\
\hline
\end{tabular}


Table 3 Distribution of IS historical papers per decade

\begin{tabular}{|l|c|c|c|c|}
\hline \multicolumn{1}{|c|}{ Decades } & $70 \mathrm{~s}$ & $80 \mathrm{~s}$ & $90 \mathrm{~s}$ & $2000 \mathrm{~s}$ \\
\hline Supplementarist & 1 & 3 & 1 & 29 \\
\hline Integrationist & 0 & 5 & 5 & 19 \\
\hline Reorientationist & 0 & 0 & 1 & 0 \\
\hline
\end{tabular}

Figure 1 Evolution of supplementarist, integrationist and reorientationist publications in IS historical research (per decade)

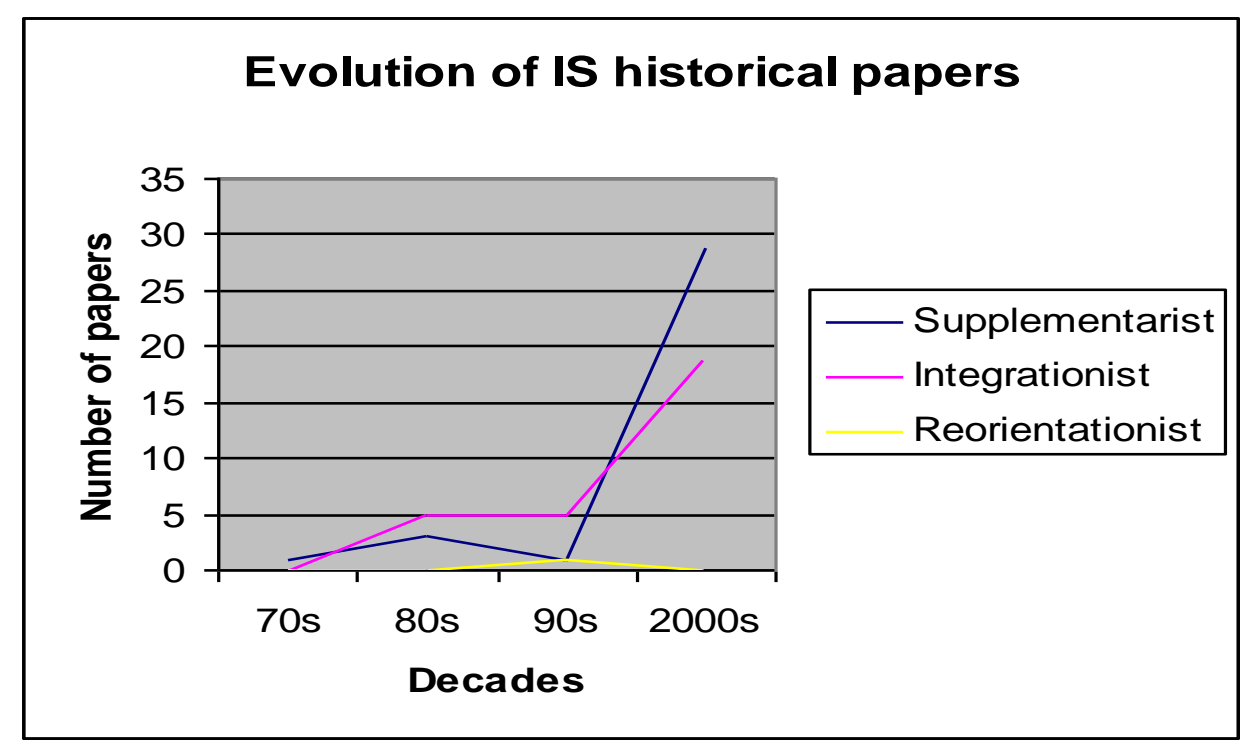

Table 4 Classification and examples of historical perspectives in IS research

\begin{tabular}{|l|l|}
\hline $\begin{array}{c}\text { HISTORICAL } \\
\text { STANCES }\end{array}$ & \multicolumn{1}{|c|}{ IS HISTORICAL RESEARCH } \\
\hline Supplementarist & $\begin{array}{l}\text { See Appendix 3. Most ABI articles we found include longer time- } \\
\text { spans but use an ahistorical stance. History is only a variable. } \\
\text { Creating Better Governance of Offshore Services (Simon et al, } \\
\text { 2009) }\end{array}$ \\
\hline
\end{tabular}




\begin{tabular}{|l|l|}
\hline Integrationist & From ABI: \\
& The History of Texaco's corporate information technology function \\
& (Porra, Hirschheim and Parks, 2005). The historical perspective is \\
used to extend the general systems theory as applied to IS. & Use History to reflect on IS and large organizations (Yates, 1999). \\
IT and organizational transformation (Elbanna, 2002). \\
Cross-History of IT and organizational change in the British Census \\
from 1801-1911 (Campbell-Kelly and Aspray, 1996). \\
From Google Scholar: \\
The History of SAP proposed by Pollock and Williams (2008). \\
\hline Reorientationist & $\begin{array}{l}\text { From ABI: } \\
\text { An Historical Method for MIS Research: Steps and Assumptions } \\
\text { (Mason et al, 1997a), } \\
\text { Developing an Historical Tradition in MIS Research (Mason } \text { et al, } \\
\text { 1997b). } \\
\text { The role of IT in the transformation of work. A comparison } \\
\text { between proto and post industrial organizations. } \\
\text { Reconceptualization of the role of IT in organizations (Winter and } \\
\text { Taylor, 1996). } \\
\text { From Google Scholar: } \\
\text { Drawing on structuration theory, Yates (1999) shows the } \\
\text { "conservative influence of existing patterns" (in the insurance } \\
\text { industry of the 50s) which is often underestimated in non-historical } \\
\text { research about IT. It sheds light on new and innovative uses of } \\
\text { computer technology in insurance from a longue durée perspective. }\end{array}$ \\
\hline
\end{tabular}

\section{APPENDIX 1 \\ Results of ABI thematic coding per year and per decade}

Request: "information systems"+"history"

Target: citation and abstract. Focused on academic (i.e. peer-reviewed) journals and those with full text version (which allowed a real exploration of abstracts and if necessary to confirm classification, the full text).

Period: 1972-2009.

Results: 384 papers, among which 64 with a non-anecdotal use of the notion of history, and 31 published in IS journals.

NB: we chose to target citation and abstract to increase the likelihood to get real History oriented papers, and not incidental uses of the notion of history. We defined a journal as an IS journal if present in the ISworld ranking.

(see: http://ais.affiniscape.com/displaycommon.cfm? an=1\&subarticlenbr=432) 


\section{Evolution per year}

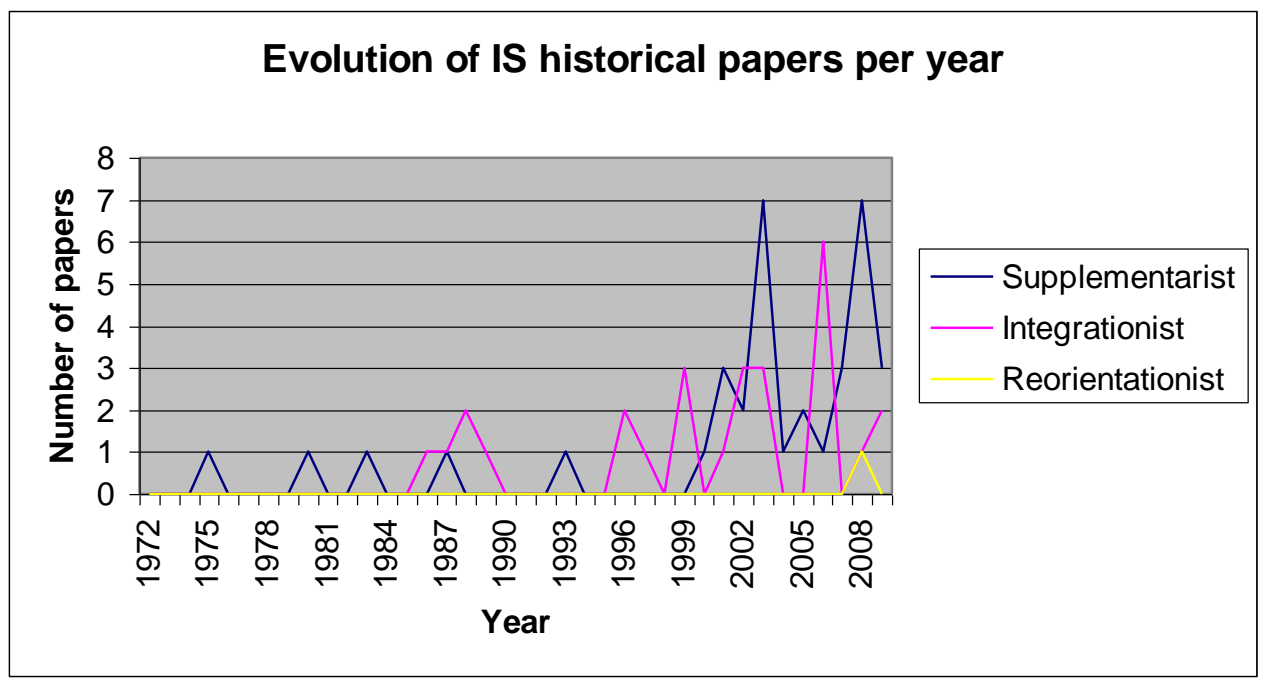

\section{Evolution per decade}

\begin{tabular}{|l|l|l|l|l|}
\hline & $70 \mathrm{~s}$ & $80 \mathrm{~s}$ & $90 \mathrm{~s}$ & $2000 \mathrm{~s}$ \\
\hline Supplementarist & 1 & 3 & 1 & 29 \\
\hline Integrationist & 0 & 5 & 5 & 19 \\
\hline Reorientationist & 0 & 0 & 1 & 0 \\
\hline
\end{tabular}

\section{APPENDIX 2}

Distribution of historical stance (supplementarist, integrationist or reorientationist) in IS papers published in academic journals overall and in IS journals in particular. 

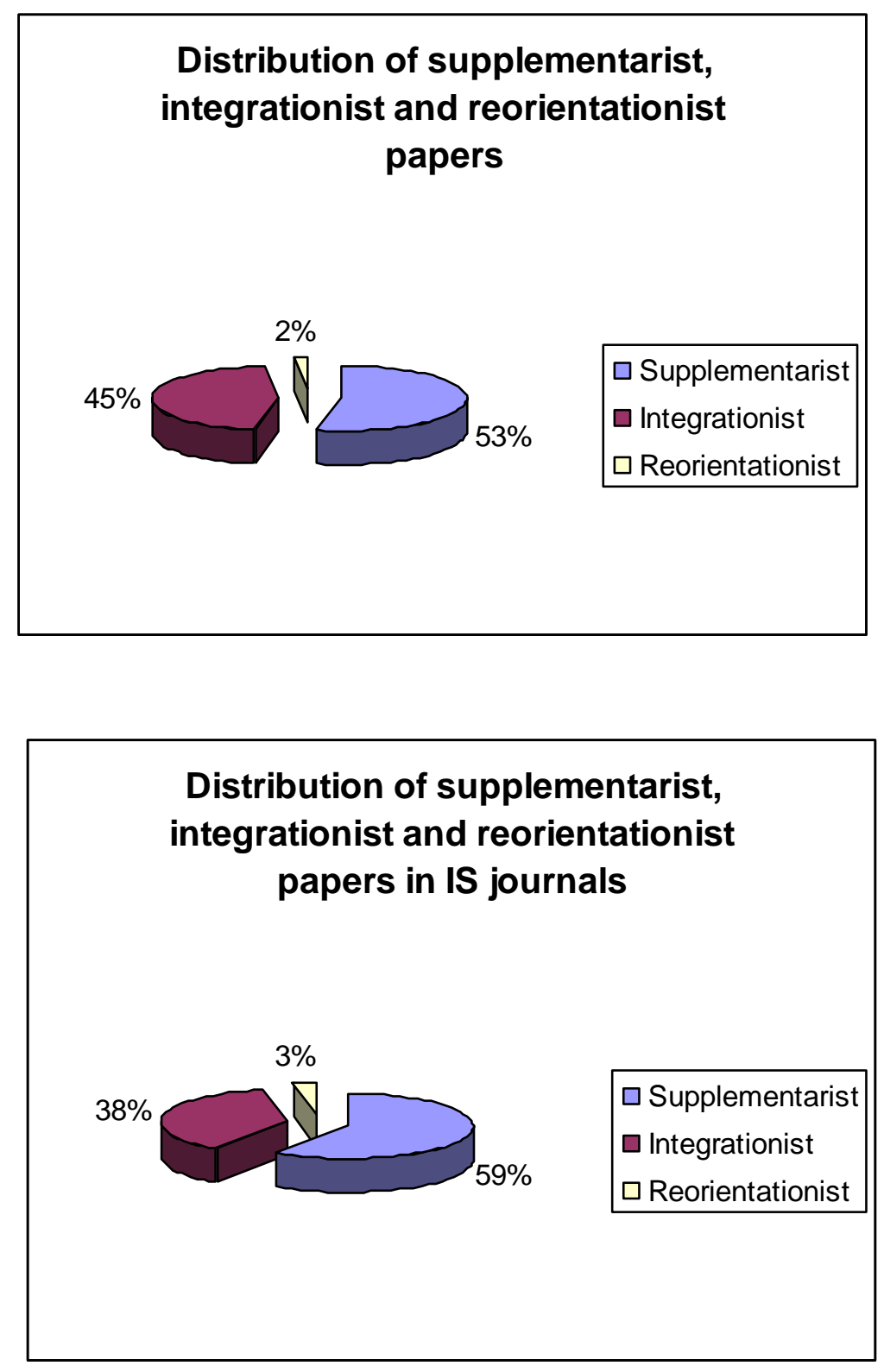

\section{APPENDIX 3 \\ Coding of a selection of historical papers (from ABI)}

\section{Classification scheme applied for our coding: NR, S, I or R}

NR: Not Relevant, rejected. Only incidental use of historical approaches. The word "history" is used in the paper, but only incidentally.

S: Supplementarist. An historical perspective is claimed. But it is only a case narrative or the use of long-term data without any specific conceptualisation. Historical material is 
not used to produce a specific theorization. Nor do authors use historical concepts or methods.

I: Integrationist. Historical material is used to produce a specific theorization. Alternatively, authors use historical concepts or methods. This is done so as to extend current theories.

R: Re-orientationist. Historical material is used to produce a specific theorization. Alternatively, authors use historical concepts or methods. This is not done to extend current theories. It is done to develop specific theorizations about historical perspectives on IS.

Extract of the thematic coding (full list of 54 pages is available upon request)

\begin{tabular}{|l|c|}
\hline \multicolumn{1}{|c|}{ ARTICLES } & CODING \\
\hline 1. & NR \\
The Influence of Weather Conditions on the Relative Incident Rate of & \\
Fishing Vessels & \\
Yue Wu, Ronald P Pelot, Casey Hilliard. Risk Analysis. Oxford: Jul 2009. & \\
Vol. 29, Iss. 7; p. 985 & S \\
\hline $\begin{array}{l}\text { Inventory control with product returns: The impact of imperfect information } \\
\text { Marisa P de Brito, Erwin A van der Laan. European Journal of Operational } \\
\text { Research. Amsterdam: Apr 1, 2009. Vol. 194, Iss. 1; p. 85 }\end{array}$ & \\
\hline $\begin{array}{l}\text { 3. } \\
\text { Creating Better Governance of Offshore Services }\end{array}$ & S \\
Judith C Simon, Robin S Poston, Bill Kettinger. Information Systems \\
Management. Boston: Spring 2009. Vol. 26, Iss. 2; p. 110 & \\
\hline $\begin{array}{l}\text { 4. } \\
\text { Improving access to safe drinking water in rural, remote and least-wealthy } \\
\text { small islands: non-traditional methods in Chuuk State, Federated States of } \\
\text { Micronesia } \\
\text { William James Smith Jr. International Journal of Environmental Technology } \\
\text { and Management. Wolverton Mill: 2009. Vol. 10, Iss. 2; p. 167 }\end{array}$ \\
\hline $\begin{array}{l}\text { 5. } \\
\text { Modeling propensity to move after job change using event History analysis } \\
\text { and temporal GIS } \\
\text { Marie-Hélène Vandersmissen, Anne-Marie Séguin, Marius Thériault, } \\
\text { Christophe Claramunt. Journal of Geographical Systems. Heidelberg: Mar } \\
\text { 2009. Vol. 11, Iss. 1; p. 37 (29 pages) }\end{array}$ \\
\hline
\end{tabular}




\begin{tabular}{|c|c|}
\hline $\begin{array}{l}6 . \\
\text { String alignment for automated document versioning } \\
\text { Wei Lee Woon, Kuok-Shoong Daniel Wong. Knowledge and Information } \\
\text { Systems. London: Mar 2009. Vol. 18, Iss. 3; p. } 293 \text { (17 pages) }\end{array}$ & $\mathbf{S}$ \\
\hline $\begin{array}{l}7 . \\
\text { Neolithic informatics: The nature of information } \\
\text { Paul Beynon-Davies. International Journal of Information Management. } \\
\text { Kidlington: Feb 2009. Vol. 29, Iss. 1; p. 3. }\end{array}$ & $\mathbf{I}$ \\
\hline $\begin{array}{l}8 . \\
\text { A Framework for Information Systems Metaresearch: The Quest for Identity } \\
\text { Viju Raghupathi, Linda Weiser Friedman. Communications of the } \\
\text { Association for Information Systems. Atlanta: 2009. Vol. 24, Iss. 1; p. } 50 \text {. }\end{array}$ & NR \\
\hline $\begin{array}{l}9 . \\
\text { Explaining information systems change: a punctuated socio-technical change } \\
\text { model } \\
\text { Kalle Lyytinen, Mike Newman. European Journal of Information Systems. } \\
\text { Basingstoke: Dec 2008. Vol. 17, Iss. 6; p. } 589 \text { (25 pages). }\end{array}$ & $\mathbf{I}$ \\
\hline $\begin{array}{l}10 . \\
\text { Credit Information System Act } \\
\text { Anonymous. International Financial Law Review. London: Dec 2008/Jan } \\
\text { 2009. }\end{array}$ & NR \\
\hline $\begin{array}{l}11 . \\
\text { Supporting Spatial Semantics with SPARQL } \\
\text { Dave Kolas. Transactions in GIS. Oxford: Dec 2008. Vol. 12, Iss. s1; p. } 5 .\end{array}$ & NR \\
\hline $\begin{array}{l}12 . \\
\text { Changes in the importance of topics in auditing education: 2000-2005 } \\
\text { Jack Armitage. Managerial Auditing Journal. Bradford: 2008. Vol. 23, Iss. 9; } \\
\text { p. } 935 \text {. }\end{array}$ & NR \\
\hline$(\ldots)$ & \\
\hline
\end{tabular}

\section{Appendix 4 \\ Google Scholar Search Results}

For the query: history+"information systems", only in the title

Period: 1972-2009

Number of results: 190 


\begin{tabular}{|l|l|l|l|l|l|l|l|l|l|l|l|l|l|l|}
\hline & $1974-$ & $1975-$ & $1976-$ & $1978-$ & $1979-$ & $1980-$ & $1981-$ & $1982-$ & $1983-$ & $1984-$ & $1985-$ & $1986-$ & $1987-$ & $1988-$ \\
& 1975 & 1976 & 1977 & 1979 & 1980 & 1981 & 1982 & 1983 & 1984 & 1985 & 1986 & 1987 & 1988 & 1989 \\
\hline Year & 1 & 4 & 4 & 1 & 3 & 3 & 1 & 0 & 0 & 0 & 0 & 3 & 6 & 5 \\
\hline Total & 1 & 5 & 8 & 5 & 4 & 6 & 4 & 1 & 0 & 0 & 0 & 3 & 9 & 11 \\
\hline
\end{tabular}

\begin{tabular}{|c|c|c|c|c|c|c|c|c|c|c|c|c|c|c|}
\hline & $\begin{array}{l}1993- \\
1994\end{array}$ & $\begin{array}{l}1994- \\
1995\end{array}$ & $\begin{array}{l}1995- \\
1996\end{array}$ & $\begin{array}{l}1996- \\
1997\end{array}$ & $\begin{array}{l}1997- \\
1998\end{array}$ & $\begin{array}{l}1998- \\
1999\end{array}$ & $\begin{array}{l}1999- \\
2000\end{array}$ & $\begin{array}{l}2000- \\
2001\end{array}$ & $\begin{array}{l}2001- \\
2002\end{array}$ & $\begin{array}{l}2002- \\
2003\end{array}$ & $\begin{array}{l}2003- \\
2004\end{array}$ & $\begin{array}{l}2004- \\
2005\end{array}$ & $\begin{array}{l}2005- \\
2006\end{array}$ & $\begin{array}{l}2006- \\
2007\end{array}$ \\
\hline Year & 5 & 6 & 4 & 5 & 10 & 28 & 15 & 6 & 5 & 12 & 18 & 13 & 20 & 20 \\
\hline Total & 18 & 24 & 28 & 33 & 43 & 71 & 86 & 92 & 97 & 109 & 127 & 140 & 160 & 180 \\
\hline
\end{tabular}

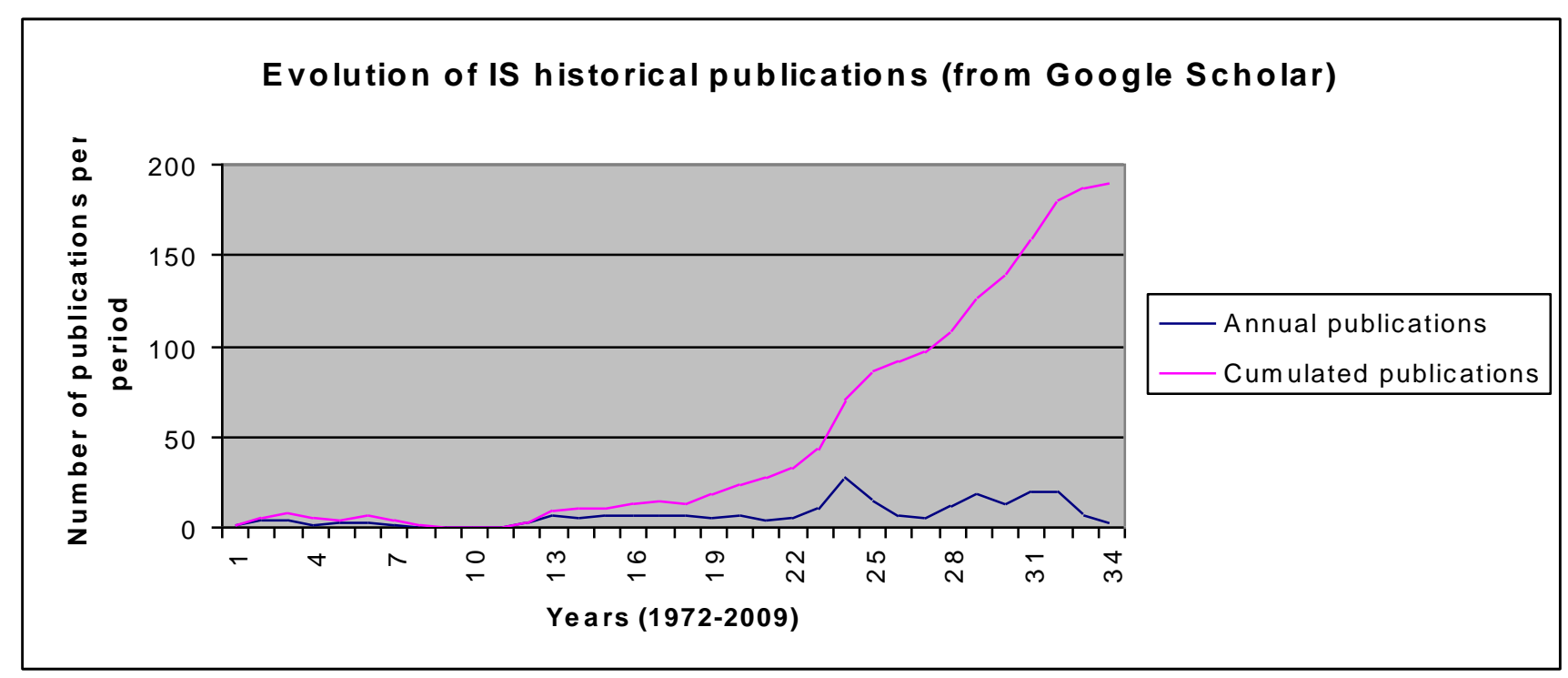

